Click www.researchjournal.co.in/online/subdetail.html to purchase.

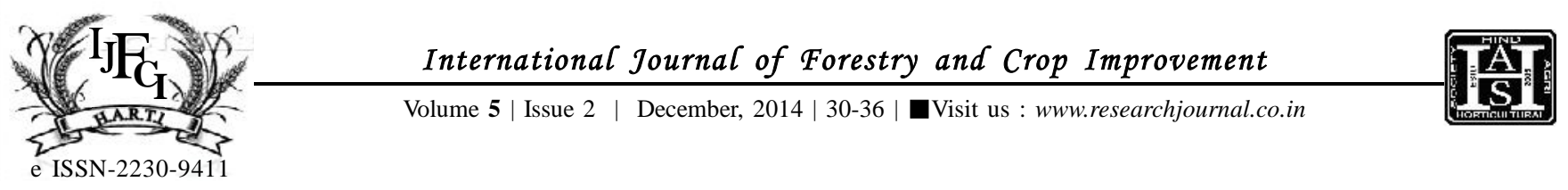

Research Article

DOI: $10.15740 / \mathrm{HAS} / \mathrm{IJFCI} / 5.2 / 30-36$

\title{
Effect of various plant growth promoters and growing conditions on flowering of Dendrobium cv. EARSAKUL
}

\author{
M. RAJANAIK AND K. AJITHKUMAR
}

\begin{abstract}
The investigation on 'Flowering response of Dendrobium cv. EARSAKUL to plant growth promoters in different growing conditions' was conducted at College of Horticulture, Vellanikkara, Kerala. Results revealed that, among plant growth promoters, the treatment $\mathrm{POP}+\mathrm{OM}+\mathrm{VW}+\mathrm{PGPRE}+$ Bone meal $+\mathrm{GR}\left(\mathrm{T}_{4}\right)$ resulted in longer spike $(31.34 \mathrm{~cm})$, more flower count $(6.54)$ and longer vase life $(30.00$ days), whereas, the treatment NPK $+\mathrm{GR}+\mathrm{OM}+\mathrm{VW}+\mathrm{PGPRE}+$ Bone meal $\left(\mathrm{T}_{6}\right)$ was the best with respect to time taken for first flower opening (14.52 days) and number of spikes per plant (2.62) in six month old plants. In three year old plants, the treatment POP $+\mathrm{OM}+\mathrm{VW}$ + PGPRE + Bone meal + GR ( $\left.\mathrm{T}_{4}\right)$ was the best with respect to time taken for flowering (283.91 days), days to last flower opening (10.98 days), number of spikes (2.63) and vase life (28.26 days), whereas, length of the spike $(30.46 \mathrm{~cm})$ and number of flowers $(5.08)$ were the highest in the treatment $\mathrm{NPK}+\mathrm{GR}+\mathrm{OM}+\mathrm{VW}+\mathrm{PGPRE}+$ Bone meal $\left(\mathrm{T}_{6}\right)$. Among three systems of growing, top ventilated polyhouse $\left(\mathrm{S}_{2}\right)$ had maximum influence on flower characters. In interaction, the combination of POP $+\mathrm{OM}+\mathrm{VW}+\mathrm{PGPRE}+\mathrm{Bone}$ meal $+\mathrm{GR}\left(\mathrm{T}_{4}\right)$ and top ventilated polyhouse $\left(\mathrm{S}_{2}\right)$ was significantly superior in flower characters irrespective of the age of the plants.
\end{abstract}

KEY WORDS : Dendrobium cv. EARSAKUl, Three growing systems, Nutrients, Piriformospora indica, Flowering

How to cite this Article : Rajanaik, M. and Ajithkumar, K. (2014). Effect of various plant growth promoters and growing conditions on flowering of Dendrobium cv. EARSAKUL. Internat. J. Forestry \& Crop Improv., 5 (2) : 30-36.

Article Chronical : Received : 23.08.2014; Revised : 15.10.2014; Accepted : 01.11.2014

MEMBERS OF RESEARCH FORUM

Address of the Correspondence :

M. RAJA NAIK, Horticultural Research Station, Anantharajupet, YSR KADAPA (A.P.) INDIA

Email: naik_raja2006@rediffmail.com

Address of the Coopted Authors :

K. AJITHKUMAR, Department of Pomology and Floriculture, College of Horticulture, Vellanikkara, THRISSUR (KERALA) INDIA 